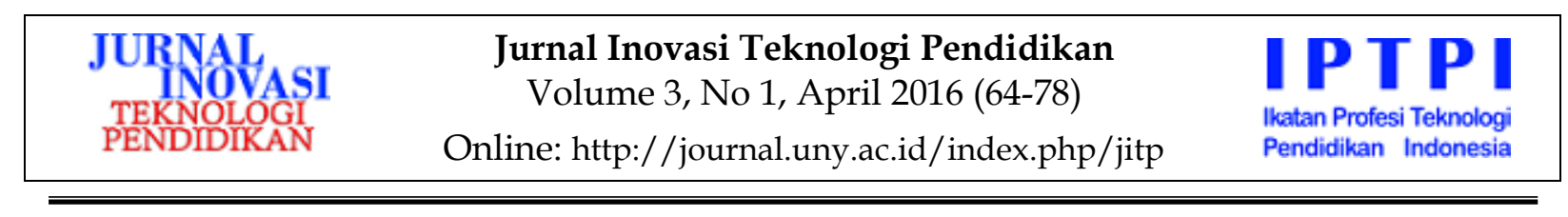

\title{
EVALUASI PELAKSANAAN PEMBELAJARAN PROGRAM STUDI DESAIN KOMUNIKASI VISUAL MSD YOGYAKARTA
}

\author{
Soraya Fatmawati, Ali Muhtadi \\ Prodi Teknologi Pendidikan Universitas Negeri Yogyakarta, Universitas Negeri Yogyakarta \\ soraya.fatma@gmail.com, alimuhtadi1@gmail.com
}

\begin{abstract}
Abstrak
Penelitian ini bertujuan untuk mengetahui kesesuaian antara pelaksanaan pembelajaran Program Studi (Prodi) DKV di ASRD MSD Yogyakarta dengan standar atau kriteria yang telah dirumuskan. Penelitian ini merupakan penelitian evaluasi dengan menggunakan model evaluasi kesenjangan. Subjek atau responden adalah Ketua Program Studi, dosen dan mahasiswa Prodi DKV MSD Yogyakarta. Penelitian ini dilaksanakan dengan menempuh 5 tahap, yaitu: penyusunan desain, penetapan kelengkapan program, pengumpulkan data, pengukuran tujuan atau analisis data, dan perbandingan. Data dikumpulkan melalui observasi, wawancara, dan dokumentasi dianalisis menggunakan model analisis interaktif dari Miles dan Huberman. Data kuesioner dianalisis menggunakan teknik statistik deskriptif dengan skala 4. Hasil penelitian menunjukkan bahwa pelaksanaan pembelajaran pada Prodi DKV MSD Yogyakarta belum sesuai dengan Permendikbud No. 49 Tahun 2014. Hasil penilaian mahasiswa menunjukkan bahwa pelaksanaan pembelajaran di Prodi DKV MSD berada pada kategori baik dengan nilai 3,20. Pembelajaran di Prodi DKV MSD Yogyakarta perlu dilaksanakan sesuai dengan Permendikbud No. 49 Tahun 2014.

Kata Kunci: pelaksanaan pembelajaran, perencanaan pembelajaran,
\end{abstract}

\section{THE EVALUATION OF INSTRUCTIONAL IMPLEMENTATION OF VISUAL COMMUNICATION DESIGN STUDY PROGRAM IN MSD YOGYAKARTA}

\author{
Soraya Fatmawati, Ali Muhtadi \\ Prodi Teknologi Pendidikan Universitas Negeri Yogyakarta, Universitas Negeri Yogyakarta \\ soraya.fatma@gmail.com, alimuhtadi1@gmail.com
}

\begin{abstract}
This research aims to determine the suitability of the instructional implementation in Visual Communication Design (VCD) Study Program of MSD Yogyakarta Design and Art Academy with standard or criteria which have been formulated. This research was an evaluation research study that refers to the discrepancy evaluation model. The subjects consisted of the head of study program, lecturers and students of VCD study program MSD Yogyakarta. The research was conducted in five stages: design preparation, determination of the program's completeness, data collection, purpose measurement or data analysis, and comparison. Data were collected through observation, interviews, and document searches, and were analyzed using an interactive analysis model proposed by Miles and Huberman. The questionnaire data were analyzed using descriptive statistical analysis in the scale 4. The result of the study shows that instructional implementation in Visual Communication Design Study Program of MSD Yogyakarta is not suitable to the Minister of Education and Culture Regulation No. 49, 2014. The result of student assessment indicates that the instructional implementation in VCD MSD Yogyakarta is categorized good with the value of 3.20. The instructional implementation in Visual Communication Design Study Program of MSD Yogyakarta needs to be adjusted with the National Standards for Higher Education the Minister of Education and Culture Regulation No. 49, 2014 for the instructional implementation can be presented.
\end{abstract}

Keywords: instructional implementation, instructional planning. 



\section{Pendahuluan}

Pendidikan tinggi menurut Undang-undang Sistem Pendidikan Nasional Nomor 20 Tahun 2003 merupakan jenjang pendidikan setelah pendidikan menengah yang mencakup program Diploma, Sarjana, Magister, Spesialis dan Doktor yang diselenggarakan oleh Pendidikan Tinggi. Pendidikan tinggi di Indonesia merupakan bagian dari sistem pendidikan nasional yang menjadi tolak ukur dalam menghasilkan tenaga kerja profesional. Perguruan tinggi negeri maupun swasta harus terus melakukan upaya untuk mendidik, melatih dan memberikan pengalaman serta keterampilan kepada peserta didik agar pada saat berada di lapangan kerja mereka siap menghadapi tantangan.

Diploma III merupakan jenjang pendidikan tinggi yang menyiapkan tenaga profesional pada tingkat ahli madya. Berdasarkan Kerangka Kualifikasi Nasional Indonesia (KKNI) jenjang D3 diharapkan menghasilkan lulusan yang (1) mampu menyelesaikan pekerjaan berlingkup luas, memilih metode yang sesuai dari beragam pilihan yang sudah maupun belum baku dengan menganalisis data, serta mampu menunjukkan kinerja dengan mutu dan kuantitas yang terukur (2) menguasai konsep teoretis bidang pengetahuan tertentu secara umum, serta mampu memformulasikan penyelesaian masalah prosedural (3) memiliki kemampuan mengelola kelompok kerja dan menyusun laporan tertulis secara komprehensif (4) bertanggung jawab pada pekerjaan sendiri dan dapat diberi tanggung jawab atas pencapaian hasil kerja kelompok (DIKTI, 2010, p.22). Oleh karena itu, lulusan tersebut diharapkan mampu memenuhi kebutuhan lapangan kerja dan membekali diri secara profesional agar dapat berkembang sesuai kemajuan ilmu pengetahuan dan tuntutan global.

Permasalahan yang muncul ialah tidak seimbangnya antara jumlah lulusan tiap tahunnya dengan jumlah lapangan kerja yang tersedia di lapangan. Berdasar- kan data dari Badan Pusat Statistik (BPS) pada bulan Februari tahun 2013 saja terdapat pengangguran terbuka di Indonesia yang jumlahnya mencapai 7,17 juta orang. (Suryawati, 2013). Dari jumlah 7,17 juta orang tersebut, terdapat sekitar 610 ribu orang merupakan pengangguran intelektual yang terdiri dari pengangguran lulusan pendidikan diploma I/II/III yang jumlahnya mencapai 192.762 orang dan lulusan universitas sebanyak 421.717 orang (Gunadha, 2013). Sementara dari laman Depnakertrans, p-merintah memprediksi dapat membuka lapangan kerja sebesar 2,5 juta kesempatan kerja pada tahun 2013. Melihat tidak seimbangnya jumlah antara kesempatan kerja yang terbuka dengan jumlah pengangguran yang ada di Indonesia, masyarakat dituntut untuk terus belajar dan meningkatkan kompetensinya agar mampu bersaing di lapangan kerja sejalan dengan kemajuan teknologi.

Bidang kerja yang mengalami kemajuan yaitu industri kreatif yang salah satu contohnya adalah desain komunikasi visual atau lebih dikenal dengan istilah desain grafis. Hal tersebut terjadi disebabkan oleh semakin terbukanya pikiran masyarakat ditambah dengan teknologi yang semakin maju sehingga ide-ide kreatif juga terus bermunculan. Oleh sebab itu, kemajuan tersebut memicu lembaga pendidikan untuk meyelenggarakan berbagai jenjang pendidikan yang mempelajari tentang desain komunikasi visual.

Di Indonesia ada banyak program studi desain komunikasi visual (DKV) baik yang diselenggarakan oleh Perguruan Tinggi Negeri (PTN) maupun Perguruan Tinggi Swasta (PTS). Contohnya di Yogyakarta, ada beberapa Perguruan Tinggi yang menyelenggarakan program studi DKV yaitu Institut Seni Indonesian (ISI) Yogyakarta, Akademi Seni Rupa dan Desain "Modern School of Desain" (ASRD MSD) Yogyakarta, Sekolah Tinggi Seni Rupa dan Desain Visi (STSRD Visi) Yogyakarta, Universitas Kristen Duta Wacana (UKDW) dan Politeknik Seni PPPPTK Seni dan Budaya. PTN dan PTS tersebut menyelenggarakan 
jenjang pendidikan yang beragam dari mulai jenjang D3 hingga Pascasarjana. Salah satu PTS di Yogyakarta yang khusus hanya menyelenggarakan satu Program Studi (Prodi) Desain Komunikasi Visual saja adalah Akademi Seni Rupa dan Desain "Modern School of Desain" Yogyakarta (ASRD MSD) yang menyelenggarakan jenjang program D3.

Berdasarkan hasil observasi yang telah dilakukan, MSD merupakan Perguruan Tinggi Swasta yang berbentuk Akademi di Yogyakarta yang telah menghasilkan banyak lulusan yang kompeten dalam bidang DKV. Tujuan yang diharapkan MSD adalah mempersiapkan insan kreatif, profesional, berjiwa wirausaha, berwawasan global, inovatif dan bermoral Pancasila (Prasetyahadi, 2012, p.3). Berdasarkan hasil wawancara terhadap salah satu pimpinan kampus tersebut pada tanggal 30 Oktober 2013, dinyatakan bahwa alumni MSD telah tersebar di berbagai perusahaan besar di Indonesia.

Berdasarkan hasil wawancara yang telah dilakukan terhadap 30 orang mahasiswa MSD secara acak dan tidak terstruktur antara tanggal 4 sampai tanggal 8 November 2013, diketahui bahwa MSD merupakan Perguruan Tinggi yang menurut mereka mampu mengajarkan ilmu tentang desain komunikasi visual yang kreatif dan lengkap serta meningkatkan keterampilan mahasiswa agar lebih baik dan mampu bersaing di lapangan kerja. Meskipun pendapat mahasiswa tersebut benar, namun hal itu bertentangan dengan fakta-fakta yang diperoleh bahwa banyak mahasiswa yang mengalami kendala-kendala di tengah perkuliahan.

Data yang diperoleh dari Pangkalan Data Pendidikan Tinggi (PDPT) MSD pada semester genap tahun ajaran 2013/ 2014 menunjukkan bahwa lama studi ratarata mahasiswa adalah 8,45 semester. Data tersebut menunjukkan bahwa mahasiswa MSD cenderung menempuh studi lebih lama dari Standar Nasional Pendidikan Tinggi (SNPT) yang telah ditetapkan. Lama studi mahasiswa tersebut bisa jadi dipe- ngaruhi oleh kondisi mahasiswa yang biasanya sudah membuka usaha atau bekerja sebelum lulus kuliah.

Data lain yang diperoleh dari PDPT MSD adalah rerata Indeks Prestasi Semester (IPS) dan Indeks Prestasi Kumulatif (IPK) mahasiswa MSD. Data tersebut menunjukkan bahwa rerata IPS dan IPK mahasiswa MSD pada semester genap tahun ajaran 2013/2014 adalah sebesar 2,25 untuk IPS dan 2,60 untuk IPK. Data tersebut menunjukkan bahwa rerata IPS dan IPK mahasiswa MSD belum mencapai kategori memuaskan $(2,76$ sampai 3,00) jika disesuaikan dengan standar penilaian pembelajaran dalam Permendikbud nomor 49 tahun 2014 tentang Standar Nasional Pendidikan Tinggi. Kurangnya rerata IPS dan IPK mahasiswa tersebut dapat disebabkan oleh masalah yang belum terungkap.

Selain data yang diperoleh melalui PDPT MSD, data yang dihimpun dari bagian Akademik MSD ditemukan fakta bahwa dari total mahasiswa selama 13 angkatan yang berjumlah 1757 orang terdapat sebanyak 489 orang atau sebesar $28 \%$ mahasiswa yang drop out (DO) dan mengundurkan diri. Banyaknya mahasiswa drop out maupun yang mengundurkan diri dari MSD disebabkan oleh faktor-faktor yang belum diungkap secara rinci. Selain data yang mengungkap tentang banyaknya mahasiswa yang keluar dari MSD, di lapangan juga ditemukan data tentang tingkat kelulusan mahasiswa tepat waktu selama 6 semeter. Data yang ditemukan menunjukkan bahwa selama kurun waktu 12 tahun MSD berdiri dan mendidik mahasiswa sebanyak 1757 orang, jumlah mahasiswa yang lulus tepat waktu selama 6 semester ada 118 orang atau sekitar 6,7\%. Jika dibandingkan dengan data mahasiswa yang keluar yaitu sebanyak 489 orang atau $28 \%$ mahasiswa yang DO dan mengundurkan diri, hal tersebut menjadi tidak seimbang.

Selain data-data yang diungkap baik dari Akademik MSD maupun dari data PDPT di atas yang bertentangan dengan pendapat positif mahasiswa tentang perkuliahan di MSD, pendapat lain yang diung- 
kap oleh sebagian mahasiswa yang diwawancara adalah dari segi pelaksanaan pembelajarannya. Menurut salah satu mahasiswa, perkuliahan yang terselenggara lebih menyenangkan pada mata kuliah praktik dari pada mata kuliah teori. Selain itu, dari faktor tenaga pengajarnya juga lebih menyenangkan dosen yang mengampu mata kuliah praktik dari pada mata kuliah teori. Proporsi mata kuliah yang ada di Program Studi DKV MSD yaitu 30\% untuk mata kuliah teori, $70 \%$ untuk mata kuliah praktik dan proporsi tersebut telah sesuai dengan Permendiknas. Sehingga, dilihat dari proporsi mata kuliah dan pendapat mahasiswa tersebut mengindikasikan bahwa pelaksanaan pembelajaran pada mata kuliah teori cenderung kurang mampu menarik perhatian mahasiswa. Kecenderungan tersebut nampak pada hasil laporan akhir semester di mana lebih banyak mahasiswa yang gagal mengikuti ujian akhir semester (UAS) pada mata kuliah teori dari pada mata kuliah praktik.

Dari observasi lapangan awal dan wawancara tidak terstruktur dengan pimpinan, dosen maupun mahasiswa, MSD membutuhkan adanya evaluasi terhadap pelaksanaan pembelajaran agar dapat diketahui faktor-faktor yang mempengaruhi kualitas pembelajaran yang ada di sana. Selama ini evaluasi yang dilakukan belum secara menyeluruh dan belum melibatkan seluruh komponen pembelajaran yang ada di MSD. Selain itu, evaluasi yang secara khusus dilakukan pada pelaksanaan pembelajaran juga belum dilakukan secara maksimal sehingga faktor penguat maupun penghambat pelaksanaan pembelajaran belum diketahui secara maksimal.

Ada banyak metode evaluasi, salah satunya adalah metode evaluasi kesenjangan atau discrepancy evaluation. Evaluasi discrepancy adalah metode evaluasi yang menekankan pada adanya kesenjangan dalam pelaksanaan prorgam (Arikunto, 2004, p.31). Tujuan evaluasi ini adalah untuk mengetahui tingkat kesesuaian antara standar dengan kinerja (performance) dari program. Bentuk perbandingan antara standar dengan kinerja yang dihasilkan nantinya adalah sebuah informasi kesenjangan yang akan dikembalikan kepada lembaga sehingga dapat dijadikan acuan untuk menentukan kebijakan selanjutnya. Kunci utama dalam evaluasi ini adalah standar atau kriteria yang telah ditetapkan berdasarkan peraturan perundangan yaitu Permendikbud Nomor 49 Tahun 2014 tentang Standar Nasional Pendidikan Tinggi, dan teori relevan yang meliputi aspek pembelajaran, tahapan pembelajaran, keterlibatan pendidik dan peserta didik dalam pembelajaran. Evaluasi terhadap pelaksanaan pembelajaran tersebut terkait dengan perencanaan, pelaksanaan pembelajaran, penilaian hasil belajar dan sarana prasarana pendukung pembelajaran. Diharapkan hasil evaluasi tersebut merupakan sumbangan pemikiran bagi penyelenggara MSD untuk perbaikan terhadap kualitas penyelenggaran pendidikan di lembaga tersebut.

Penelitian ini bertujuan untuk mengetahui kesesuaian antara pelaksanaan pembelajaran yang terjadi di Program Studi DKV di ASRD MSD Yogyakarta dengan standar atau kriteria yang telah dirumuskan. Hasil penelitian ini memberikan beberapa manfaat, yaitu: secara teoritis, hasil penelitian ini sebagai salah satu informasi yang dapat digunakan sebagai bahan acuan dalam penelitian ataupun kajian selanjutnya tentang pelaksanaan pembelajaran dengan model evaluasi kesenjangan yang melihat kesesuaian antara standar dengan kinerja (performance) dari suatu program. Secara praktis, bagi pengelola lembaga dapat menjadi bahan rujukan untuk pengelolaan dan pengambilan keputusan tentang pelaksanaan pembelajaran di Prodi DKV MSD Yogyakarta selanjutnya sehingga dapat memperbaiki dan juga meningkatkan kualitas pembelajarannya. Bagi peneliti diharapkan dapat memberi sumbangan penelitian khususnya tentang evaluasi yang berkaitan dengan pelaksanaan pembelajaran di Perguruan Tinggi serta dapat dijadikan sebagai bahan perbandingan untuk penelitian yang relevan. 


\section{Metode Penelitian}

Penelitian ini dilakukan dengan tujuan untuk mengevaluasi pelaksanaan pembelajaran Program Studi DKV di Akademi Seni Rupa dan Desain MSD Yogyakarta sehingga penelitian ini dapat dikategorikan sebagai penelitian evaluasi. Penelitian ini berusaha mengungkap dan mendapatkan informasi yang akurat serta mengamati adanya fenomena tertentu dengan mendeskripsikan pelaksanaan pembelajaran di Prodi DKV MSD. Berdasarkan tujuan dari penelitian yang ingin dicapai, model evaluasi yang digunakan dalam penelitian ini adalah evaluasi kesenjangan (discrepancy) yang dikembangkan oleh Malcom Provus. Evaluasi ini merupakan evaluasi yang berusaha untuk mengidentifikasi kekurangan dan kelebihan berdasarkan standar yang telah ditetapkan. Kunci utama dalam pelaksanaan penelitian ini terletak pada penentuan standar atau kriteria yang telah ditetapkan sebelumnya. Hal ini penting, karena dalam penelitian evaluasi dengan model evaluasi discrepan$c y$, standar menjadi hal pokok yang harus dirumuskan dengan baik dan benar agar menghasilkan data yang akurat.

Tempat penelitian adalah di kampus Akademi Seni Rupa dan Disain MSD Yogyakart. Penelitian dimulai pada bulan September hingga November 2014. Subjek yang dibutuhkan dalam penelitian ini adalah satu orang Ketua Program Studi, delapan orang dosen dan 305 mahasiswa MSD Yogyakarta.

Langkah-langkah pada penelitian ini meliputi: tahap penyusunan desain, penetapan kelengkapan program, proses, pengukuran tujuan dan perbandingan. Tahap penyusunan desain yaitu: melakukan kegiatan prasurvei untuk melihat kelayakan lokasi penelitian, menyusun proposal, merumuskan kriteria berdasar pada teoriteori dan standar yang digunakan, tahap pelaksanaan dan tahap akhir. Tahap penetapan kelengkapan program, yaitu: menyusun kisi-kisi instrumen dan mengembangkannya menjadi instrumen yang diguna- kan. Tahap proses meliputi: mengumpulkan semua data yang diperlukan. Tahap pengukuran tujuan meliputi: melakukan analisis data dan menetapkan hasil yang diperoleh di lapangan. Tahap perbandingan, meliputi: membandingkan hasil yang telah diperoleh melalui analisis data dengan kriteria yang telah ditetapkan kemudian menarik kesimpulan.

Data yang dibutuhkan dalam penelitian ini yaitu data tentang pelaksanaan pembelajaran di MSD. Instrumen dan teknik pengumpulan data yang akan digunakan yaitu observasi partisipasi pasif, wawancara terstruktur dengan dosen dan Kaprodi, penelusuran dokumen dan angket penilaian pelaksanaan pembelajaran bagi mahasiswa.

Analisis data dalam penelitian ini dilakukan sejak awal dan terus-menerus sepanjang penelitian, agar diperoleh hasil sesuai dengan yang diharapkan. Data kualitatif yang dikumpulkan melalui teknik observasi, wawancara dan dokumenta-i dianalisis secara deskriptif kualitatif dengan menggunakan teknik analisis model Miles dan Huberman yang meliputi tiga proses yaitu reduksi data, penyajian data, dan pengambilan kesimpulan (Sugiyono, 2013, p.92)

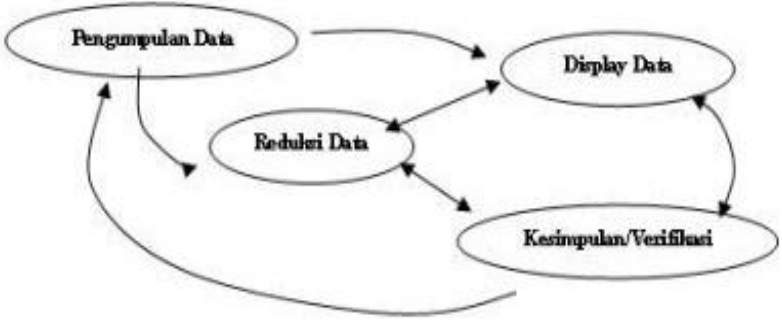

Gambar 1. Analisis data model Miles dan Huberman

Teknik analisis data yang digunakan pada data kuantitatif yang berasal dari hasil kuesioner dianalisis dengan menggunakan statistik deskriptif dengan penyajian tabel berdasarkan kategori. Penentuan kategori tersebut mengacu pada perhitungan menurut Widoyoko (2013, p.110).

$$
\text { Jarak Interval }=\frac{\text { skor tertinggi }- \text { skor terendah }}{\text { Jumlah kelas interval }}
$$


Setelah jarak interval diketahui, tabel kualifikasi dalam kuesioner dapat ditentukan. Dengan demikian dapat diketahui sejauh mana penilaian mahasiswa tentang pelaksanaan pembelajaran pada Program studi DKV MSD Yogyakarta. Berikut adalah tabel kualifikasi penilaian mahasiswa terhadap pelaksanaan pembelajaran yang mengacu pada perhitungan menurut Widoyoko (2013, p.110).

Tabel 1. Kualifikasi Perolehan Skor Penilaian terhadap Pelaksanaan Pembelajaran

\begin{tabular}{cc}
\hline Jumlah Perolehan Skor & Kategori \\
\hline $3,25-4,00$ & Sangat baik \\
$2,50-3,25$ & Baik \\
$1,75-2,50$ & Kurang Baik \\
$1,00-1,75$ & Tidak baik \\
\hline
\end{tabular}

\section{Hasil Penelitian dan Pembahasan}

Evaluasi yang dilakukan di ASRD MSD Yogyakarta menggunakan berbagai teknik pengumpulan data tersebut disamping untuk melihat gambaran pelaksanaan pembelajaran yang terjadi juga untuk melihat ada tidaknya kesenjangan atau sudah sesuaikah pembelajaran. Kesesuaian maupun kesenjangan tersebut dilihat dari kriteria atau standar yang telah ditentukan sebelumnya berdasarkan teori-teori yang relevan maupun peraturan-peraturan yang berlaku baik Peraturan Pemerintah, Peraturan Menteri maupun Undang-undang. Sehingga hasil penelitian ini dapat diteruskan kepada lembaga untuk digunakan sebagai pijakan perbaikan pembelajaran yang terjadi selama ini.

Dalam rangka penelitian tentang evaluasi pelaksanaan pembelajaran kegiatan-kegiatan yang dilakukan antara lain: (1) dimulai dari meminta ijin dengan membawa surat ijin pra-survei untuk melakukan kegiatan pra-survei; (2) kemudian melakukan kegiatan pra-survei yang dilakukan selama beberapa kali survei; (3) melaksanakan observasi pelaksanaan pembelajaran dan dokumentasi selama 6 minggu atau 6 kali observasi dalam setiap kelas di mana terdapat 26 mata kuliah dengan lebih dari 80 kelas tidak termasuk Kuliah Profesi (KP) dan Tugas Akhir (TA). Jumlah kelas yang diobservasi tidak semuanya melainkan hanya perwakilan dari mata kuliah teori dan mata kuliah praktik. Jumlah kelas yang diobservasi ada 13 kelas yang terdiri dari 5 kelas di semester I, 4 kelas di semester III dan 4 kelas di semester V. Selain itu, jumlah kelas di mata kuliah teori yang diobservasi adalah 3 kelas dan 11 kelas lainnya adalah mata kuliah praktik, baik manual maupun komputerasi; (4) melakukan kegiatan wawancara yang dilaksanakan di tiap akhir perkuliahan, sehingga tidak menganggu jalannya perkuliahan dan kesibukan setiap dosen. Jumlah dosen yang diwawancara sebanyak 8 orang dosen dan 1 orang Ketua Prodi; (5) sementara untuk pengisian angket atau kuesioner oleh mahasiswa dilakukan pada minggu ke 7 di tiap akhir sesi perkuliahan, namun tidak semua kelas yang diambil untuk mengisi angket, hanya perwakilan tiap mata kuliah. Jumlah kelas yang diberi angket adalah 13 kelas dengan total mahasiswa 305 orang.

Selama melakukan kegiatan penelitian di lingkungan ASRD MSD Yogyakarta tersebut, fokus penelitian adalah perencanaan perkuliahan, pelaksanaan pembelajarannya, evaluasi hasil belajar dan komponen pendukung pembelajaran seperti sarana dan prasarana yang tersedia sebagai pendukung perkuliahan. Dalam pelaksanaan pembelajaran hal yang diamati yaitu aktivitas dosen dan interaksi antara dosen dengan mahasiswa. Pada aktifitas dan interaksi dosen dengan mahasiswa meliputi kehadiran, alokasi waktu, kemampuan dosen memotivasi mahasiswa, kemampuan dosen menjelaskan materi perkuliahan, kemampuan dosen dalam menerapkan berbagai metode pembelajaran, ketersediaan media pembelajaran hingga partisipasi maupun perhatian mahasiswa selama mengikuti pembelajaran.

Keberhasilan pelaksanaan pembelajaran sangat tergantung pada dukungan 
dari semua komponen pembelajaran. Evaluasi terhadap pelaksanaan pembelajaran di MSD ini dapat dilihat dari ada tidaknya kesenjangan antara kriteria atau standar pelaksanaan pembelajaran yang telah ditetapkan sebelumnya dengan kondisi yang terjadi di lapangan. Secara keseluruhan, pelaksanaan pembelajaran yang terjadi di Prodi DKV MSD Yogyakarta belum sesuai dengan Permendikbud nomor. 49 tahun 2014.

\section{Perencanaan Pembelajaran}

Keberhasilan pelaksanaan pembelajaran dalam kelas manapun segala sesuatunya berasal dari dukungan seluruh komponen pembelajaran. Selain dukungan dari seluruh komponen pembelajaran, yang sangat penting dalam sebuah pelaksanaan pembelajaran adalah perencanaannya yang matang. Dapat dikatakan bahwa perencanaan yang matang merupakan bagian dari proses pelaksanaan pembelajaran yang hampir selesai. Dalam sebuah perencanaan atau dapat dikatakan persiapan pembelajaran, pendidik sebagai lokomotif dalam kelas perlu mempertimbangkan hal-hal seperti materi yang akan diajarkan, cara mengajarkan materi dan cara memastikan peserta didik mampu mempelajari materi yang diajarkan.

Dalam kegiatan pembelajaran di ASRD MSD Yogyakarta perencanaan pembelajaran juga merupakan bagian yang wajib dalam persiapan perkuliahan. Rangkaian persiapan perkuliahan yang dilakukan oleh dosen-dosen MSD adalah kegiatan seperti menyiapkan silabus yang berisi tujuan pembelajaran yang akan disampaikan kepada mahasiswa, menyiapkan materi perkuliahan, menyiapkan kelas dan menyiapkan mahasiswa agar mampu menerima dan menyerap materi perkuliahan dengan baik.

Dari hasil penelitian di MSD Yogyakarta dapat disimpulkan bahwa belum adanya pedoman yang jelas/aturan-aturan baku dalam penyusunan silabus dan materi perkuliahan. Selain itu, belum ada standar atau format yang jelas hal-hal apa saja yang perlu dimasukkan dalam penyusunan silabus. Sehingga silabus dan materi perkuliahan antara satu dosen dengan yang lainnya berbeda-beda. Penyusunan silabus yang diserahkan sepenuhnya kepada dosen tersebut belum mengacu pada Standar Proses Pembelajaran Permendikbud no. 49 tahun 2014. Dalam peraturan tersebut disebutkan bahwa silabus atau RPS memuat komponen nama program studi, nama dan kode mata kuliah, semester, sks, nama dosen pengampu, capaian pembelajaran lulusan, kemampuan akhir yang direncanakan, bahan kajian yang terkait, metode pembelajaran, pengalaman belajar mahasiswa dan sebagainya. Sementara silabus-silabus yang diamati masih ada beberapa yang belum memuat komponen-komponen seperti pada Permendikbud no. 49 tahun 2014. Kesimpulan lain yang tersirat dalam penyusunan dan penggunaan silabus di Prodi DKV MSD adalah tidak adanya koordinasi antara tiap-tiap dosen, sehingga silabus tiap mata kuliah berbeda-beda.

Selain silabus, hal lain yang dapat disimpulkan adalah dalam penyusunan materi perkuliahan yang belum menggunakan langkah-langkah yang sesuai dengan teori yaitu menentukan kompetensi pembelajaran, kemudian menentukan tujuan pembelajaran yang ingin dicapai dan terakhir baru menentukan materi pembelajaran (Gafur, 2012, p.70). Meskipun dalam menentukan materi perkuliahan tidak sesuai dengan langkah-langkah pemilihan materi, namun pengorganisasian materi perkuliahan telah oleh dosen-dosen Prodi DKV MSD dari yang sederhana dan konkret menuju ke kompleks dan abstrak. Hal tersebut terlihat pada observasi lapangan yang dilakukan di mana tingkat kesulitan materi akan selalu meningkat di tiap pertemuannya.

\section{Pelaksanaan Pembelajaran}

Pelaksanaan pembelajaran mengacu pada teori yang dikembangkan oleh 
Gagne tentang 9 kejadian pembelajaran atau Gagne's nine events of instruction (Gagne, et al, 2004, p.157) yang terdiri atas urutan-urutan pembelajaran yang perlu dilakukan oleh tenaga pengajar. Kesembilan kejadian pembelajaran menurut Gagne tersebut secara garis besar terangkum dalam tiga kegiatan yaitu kegiatan pendahuluan pembelajaran, kegiatan inti pembelajaran dan kegiatan penutup pembelajaran. Hal tersebut perlu dilakukan agar pelaksanaan pembelajaran berjalan lancar dan mampu mencapai tujuan yang diharapkan.

\section{Kegiatan Pendahuluan Pembelajaran}

Dalam kegiatan pendahuluan pembelajaran, jika dilihat dari teori Gagne's nine events of instruction ada tiga poin utama dalam kegiatan ini. Pertama yaitu gaining attention atau mendapatkan perhatian dari peserta didik. Kedua adalah informing the learner of the goal atau menyampaikan kepada peserta didik tentang tujuan pembelajaran yang akan dicapai. Ketiga yaitu stimulating recall of prior knowledge atau mengaitkan dan mengingatkan kembali materi sebelumnya dengan materi yang akan dibahas pada pertemuan tersebut.

Pada kegiatan pendahuluan pembelajaran, kegiatan pertama yang dilakukan oleh dosen adalah gaining attention atau mendapatkan perhatian dari peserta didik. Berdasarkan hasil observasi kelas dan kuesioner untuk mahasiswa menunjukkan bahwa sebagian besar dosen telah mampu menarik perhatian mahasiswa sejak awal pertemuan. Hal tersebut dicatat sepanjang enam kali pertemuan perkuliahan yang diikuti antara tanggal 15 September hingga 24 Oktober 2014, rata-rata diawal pertemuan dosen-dosen MSD berusaha menarik perhatian mahasiswa dengan cara menyapa dan memanggil namanama mahasiswa sekaligus membahas sedikit tentang sesuatu hal yang sedang terjadi di masyarakat. Sehingga dari awal pertemuan perhatian mahasiswa sudah tertuju pada dosen. Meskipun tidak semua dosen melakukan kegiatan tersebut. Dari hasil catatan lapangan yang diperoleh, ada salah satu mata kuliah yang berlangsung pada tanggal 10 Oktober 2014 di mana dosen langsung memberikan materi perkuliahan tanpa didahului dengan memusatkan perhatian maupun apersepsi terhadap mahasiswa. Sehingga hal tersebut berakibat kurangnya perhatian mahasiswa dalam mengikuti jalannya perkuliahan.

Kegiatan kedua yang dilakukan oleh dosen adalah informing the learner of the goal atau menyampaikan kepada peserta didik tentang tujuan pembelajaran yang akan dicapai. Dari hasil observasi dan kuesioner mahasiswa menunjukkan bahwa dosen telah menyampaikan tujuan pembelajaran dengan baik. Mahasiswa sebagai subjek dalam pembelajaran juga memberikan penilaian yang sama bahwa dalam hal ini, dosen telah melaksanakan kegiatan tersebut sesuai dengan Gagne's nine events of instruction.

Kegiatan ketiga yaitu stimulating recall of prior knowledge atau mengaitkan dan mengingatkan kembali materi sebelumnya dengan materi yang akan dibahas pada pertemuan tersebut. Pada kegiatan tersebut tidak semua dosen melakukannya. Hal ini dibuktikan dengan beberapa catatan lapangan yang diperoleh yang menunjukkan bahwa masih ada sebagian dosen yang tidak membahas tentang materi sebelumnya melainkan langsung membahas pada materi baru.

Keseluruhan kelas yang diobservasi adalah sebanyak 13 kelas dan dapat dikatakan bahwa pada kegiatan pendahuluan pembelajaran telah berjalan dengan baik. Hal ini dibuktikan dengan catatan lapangan dari hasil observasi yang menyatakan bahwa sebagian besar dosen telah melakukan tiga kegiatan pendahuluan pembelajaran seperti yang dikemukakan oleh Gagne dalam Gagne's nine events of instruction.

\section{Kegiatan Inti Pembelajaran}

Sesuai dengan teori Gagne's nine events of instruction, yang terjadi dalam 
kegiatan inti pembelajaran adalah presenting the stimulus material atau menyajikan materi sebagai rangsangan kepada peserta didik. Kegiatan kedua yang dilakukan dalam pembelajaran inti ialah providing learning guidance atau memberikan bimbingan atau petunjuk belajar kepada peserta didik. Ketiga adalah eliciting the performance (practice) yaitu mengaktifkan peserta didik dengan praktik-praktik yang dapat mempermudah pemahaman atau kemampuan mereka tentang materi yang sedang diajarkan. Aktivitas terakhir dalam rangkaian kegiatan inti pembelajaran adalah providing feedback about performance correctness di mana tenaga pengajar memberikan umpan balik tentang praktik-praktik yang telah dikerjakan.

Dalam inti pembelajaran kegiatan yang pertama adalah presenting the stimulus material atau menyajikan materi sebagai rangsangan kepada peserta didik. Hal yang dapat menjadi rangsangan atau stimulus kepada mahasiswa di MSD adalah dengan memberikan pertanyaan-pertanyaan "pancingan" atau pertanyaan yang mengandung interaksi. Dari hasil observasi dan catatan-catatan yang dihimpun di lapangan, menunjukkan bahwa sebagian besar dosen merangsang mahasiswanya dengan pertanyaan-pertanyaan. Dibeberapa kelas mahasiswa terlihat antusias namun disebagian kelas lain menunjukkan mahasiswa terlihat kurang antusias. Tidak antusiannya mahasiswa tersebut lebih jelas terlihat pada mata kuliah yang melibatkan mahasiswamahasiswa angkatan lama dan pada mata kuliah-mata kuliah teori. Seperti catatan lapangan yang diperoleh pada mata kuliah Teknik Presentasi semester V tanggal 25 September 2014 terungkap bahwa pada saat dosen menjelaskan materi tentang teknik presentasi dan mengajukan pertanyaanpertanyaan nampak mahasiswa kurang antusias dan diam saja, bahkan ada satu mahasiswa yang tertidur dalam kelas.

Kegiatan inti pembelajaran yang kedua pada Gagne's nine events of instruction adalah providing learning guidance atau memberikan bimbingan atau petunjuk bel- ajar kepada peserta didik. Pemberian petunjuk ini dilakukan oleh dosen setelah menyampaikan materi perkuliahan. Pada salah satu perkuliahan Mata Kuliah Menggambar I yang diamati pada tanggal 29 September 2014 pemberian petunjuk dilakukan dengan pemberian contoh terlebih dahulu dan pemberian aturan-aturan yang perlu diperhatikan oleh mahasiswa. Kemudian setelah pemberian petunjuk dosen membagikan kertas sebagai alat untuk mengerjakan tugas yang diberikan oleh dosen.

Tahap ketiga pada Gagne's nine events of instruction adalah eliciting the performance (practice) yaitu mengaktifkan peserta didik dengan praktik-praktik yang dapat mempermudah pemahaman atau kemampuan mereka tentang materi yang sedang diajarkan. Kegiatan ini dilakukan oleh hampir seluruh dosen pengampu mata kuliah mengingat proporsi yang paling tinggi terletak pada peningkatan keterampilan. Sehingga praktikum atau praktik langsung dianggap sebagai kegiatan sehari-hari. Dari hasil observasi dan catatan lapangan yang diperoleh pada rentang waktu tanggal 15 September hingga 24 Oktober 2014 menunjukkan bahwa hampir seluruh mata kuliah menngunakan metode pembelajaran praktikum atau praktik langsung. Sehingga praktikum tersebut memaksa mahasiswa untuk selalu aktif dalam mengerjakan tugas praktik-praktik tertentu.

Tahap keempat pada Gagne's nine events of instruction adalah providing feedback about performance correctness di mana tenaga pengajar memberikan pembimbingan dan pengarahan atau pemberian umpan balik tentang praktik-praktik yang seharusnya dikerjakan. Pengarahan tentang praktikpraktik tersebut dimaksudkan dengan memberikan umpan balik terhadap tugastugas yang telah atau sedang dikerjakan oleh mahasiswa. Dari hasil observasi yang didapat dilapangan, hampir seluruh dosen di MSD telah maelakukan kegiatan ini. Pemberian umpan balik kepada peserta didik di MSD yang terjadi pada sela-sela pengerjaan tugas harian oleh mahasiswa. 
Dari hasil observasi yang dilakukan, pada Mata Kuliah Menggambar I tanggal 29 September 2014 diketahui bahwa pemberian umpan balik dilakukan secara tidak langsung yaitu dosen memeriksa tugas yang dikerjakan mahasiswa dengan berkeliling sekaligus memberikan arahan. Selain itu, ada pula dosen yang melakukan kegiatan tersebut dengan cara memanggil mahasiswa satu per satu.

Berdasarkan keseluruhan kelas observasi, dapat dikatakan bahwa pada kegiatan inti pembelajaran telah berjalan dengan baik. Hal ini dibuktikan dengan catatan lapangan dari hasil observasi yang menyatakan bahwa sebagian besar dosen telah melakukan empat kegiatan seperti yang dikemukakan oleh Gagne dalam Gagne's nine events of instruction.

\section{Kegiatan Penutup Pembelajaran}

Dalam kegiatan penutup pembelajaran, jika poin satu hingga tiga pada Gagne's nine events instruction termasuk dalam kategori kegiatan pendahuluan dan poin empat hingga tujuh merupakan kategori kegiatan inti pembelajaran, maka poin ke delapan dan kesembilan merupakan bagian dari kegiatan penutup pembelajaran. Kegiatan kedelapan adalah assessing the performance merupakan kegiatan untuk mengukur capaian hasil belajar peserta didik. Kegiatan kesembilan atau yang terakhir dalam sembilan kejadian pembelajaran menurut Gagne adalah enhancing retention and transfer di mana dalam kegiatan ini dosen diharapkan mampu membantu mahasiswa meningkatkan dan mengembangkan kemampuan mereka setalah adanya proses transfer pengetahuan baru.

Hasil penelitian yang telah dilakukan menunjukkan bahwa kegiatan penutup pembelajaran di MSD tidak berjalan dengan lancar dan baik sebagaimana yang terjadi pada kegiatan pendahuluan dan inti pembelajaran. Hal ini terjadi karena, pada akhir sesi perkuliahan sebagian besar mahasiswa masih berkonsentrasi pada tugastugas yang sedang dikerjakan sehingga dosen tidak sempat untuk melakukan aktivitas-aktivitas dalam kegiatan penutup.

Dalam kegiatan penutup pembelajaran yang pertama adalah assessing the performance merupakan kegiatan untuk mengukur capaian hasil belajar peserta didik. Pada pelaksanaannya di MSD, dosen mengukur capaian belajar ini dengan cara memeriksa desain tugas yang nantinya akan dikerjakan oleh mahasiswa. Memeriksa desain tugas tersebut dilakukan oleh hampir seluruh dosen MSD, sehingga ketika mahasiswa mengumpulkan tugas, tugas yang dikumpulkan merupakan tugas yang telah disetujui terlebih dahulu oleh dosen. Pada hasil observasi yang didapatkan dilapangan, salah satu contoh pada mata kuliah Menggambar I, ketika semua mahasiswa sedang mengerjakan tugas, satu per satu mahasiswa maju menemui dosen dengan membawa desain tugas yang akan dikerjakan, kemudian dosen memberi saran perbaikan atau langsung menyetujui desain tugas tersebut. Selama proses persetujuan tersebut, dosen menanyakan beberapa pertanyaan seputar pemahaman mahasiswa tentang materi perkuliahan pada pertemuan tersebut.

Proses persetujuan tersebut sebagai bentuk aktivitas assessing the performance terjadi pada mata kuliah-mata kuliah praktik, sementara pada mata kuliah teori proses tersebut terjadi pada saat dosen memberikan umpan balik berupa pertanyaan-pertanyaan atau kuis yang tidak direncanakan sebelumnya. Penilaian tersebut dosen tuliskan pada lembar penilaian harian yang memang disediakan oleh MSD untuk dosen.

Aktivitas yang kedua dalam Gagne's nine events of instruction pada kegiatan penutup adalah enhancing retention and transfer di mana dosen membantu mahasiswa meningkatkan dan mengembangkan kemampuan mereka setalah adanya proses transfer pengetahuan baru. Dari hasil di lapangan menunjukkan, pada pelaksanaan pembelajaran di MSD kegiatan ini tidak berjalan dengan maksimal. Hal ini dikarenakan, pada akhir sesi perkuliahan, 
mahasiswa sibuk mengerjakan tugas yang diberikan sementara dosen sibuk berkeliling dan memberikan bimbingan kepada mahasiswa, sehingga kegiatan merefleksi pembelajaran menjadi terabaikan.

Akhir dari kegiatan penutup pembelajaran adalah menyampaikan salam penutup, namun pada salah satu kelas yang menjadi tempat observasi hal itu tidak dilakukan. Hasil observasi kelas tersebut dicatat pada tanggal 29 September 2014 terungkap bahwa pada akhir perkuliahan dosen memanggil nama-nama mahasiswa untuk presensi dan mengumumkan pengumpulan tugas kemudian mahasiswa langsung meninggalkan kelas setelah selesai presensi. Kemudian tanpa menutup perkuliahan, dosen meninggalkan kelas walaupun masih ada mahasiswa yang belum selesai mengerjakan tugas.

Selain memberikan umpan balik dan refleksi pembelajaran salah satu kegiatan yang penting dilakukan sebelum menutup perkuliahan adalah menyampaikan sedikit tema atau tujuan pembelajaran pada pertemuan selanjutnya. Dari seluruh kelas yang diobservasi, ditemukan bahwa rata-rata dosen telah menyampaikan tujuan pembelajaran untuk pertemuan selanjutnya. Namun penyampaian tersebut tidak berjalan dengan maksimal bahkan hanya terkesan seadanya. Salah satu contoh, dari hasil observasi yang diperoleh pada mata kuliah Nirmana I tanggal 30 September 2014 didapat catatan bahwa diakhir perkuliahan dosen memberikan instruksi kepada mahasiswa untuk membawa peralatan yang dibutuhkan pada pertemuan selanjutnya tentang gaya keseimbangan dan kemudian langsung menutup perkuliahan dengan salam.

Dari hasil penelitian yang telah dilakukan, dapat disimpulkan bahwa pelaksanaan pembelajaran di MSD masih ditemui ketidaksesuaian dengan Sembilan kejadian pembelajaran Gagne yaitu pada tahap akhir pembelajaran yang berupa menyimpulkan atau refleksi pembelajaran.

Selain pengumpulan data dan penarikan kesimpulan dari observasi dan wawancara yang dilakukan selama perkuliahan berlangsung, hasil pengumpulan data dan penarikan kesimpulan dari kuesioner yang dibagikan kepada mahasiswa tentang penilaian mahasiswa terhadap pelaksanaan pembelajaran di MSD Yogyakarta menunjukkan bahwa pelaksanaan pembelajaran di MSD berada pada kategori baik atau pada hasil penilaian 3,20. Lebih lengkap dapat dilihat pada tabel berikut.

Tabel 2. Kualifikasi Perolehan Skor Penilaian terhadap Pelaksanaan Pembelajaran.

\begin{tabular}{clc}
\hline No. & Kegiatan Pembelajaran & $\begin{array}{c}\text { Hasil } \\
\text { Penilaian }\end{array}$ \\
\hline 1. & Kegiatan Pendahuluan & 3,23 \\
2. & Kegiatan Inti & 3,22 \\
3. & Kegiatan Penutup & 3,20 \\
Nilai keseluruhan Pembelajaran & 3,20 \\
\hline
\end{tabular}

Tabel 2 tentang kualifikasi perolehan skor penilaian terhadap pelaksanaan pembelajaran menunjukkan bahwa mahasiswa menilai pelaksanaan pembelajaran di MSD dalam kategori baik atau sebesar 3.20. dikatakan baik apabila perolehan nilai berada pada kisaran 2.5 hingga 3.25. Sehingga pelaksanaan pembelajaran di MSD dari mulai kegiatan pendahuluan, kegiatan inti hingga kegiatan penutup dalam kategori baik.

Meskipun mahasiswa menilai pelaksanaan pembelajaran di MSD dikatakan baik, tetap saja dalam pelaksanaannya terdapat kendala-kendala yang dihadapi oleh MSD. Dari pernyataan-pernyataan terbuka yang disampaikan oleh mahasiswa melalui kuesioner, dikumpulkan dan kemudian disimpulkan adalah mahasiswa MSD menginginkan lebih banyak praktik diluar kelas sehingga pengetahuan mereka bertambah, penyampaian materi oleh dosen cenderung membosankan terutama pada mata kuliahmata kuliah teori dan sarana prasarana seperti yang ada di Laboratorium banyak yang rusak sehingga mengganggu jalannya perkuliahan. 
Interaksi Dosen dan Mahasiswa

Pembelajaran merupakan proses dari adanya interaksi antara dosen dan mahasiswa. Selama proses tersebut, banyak aspek yang menjadi obyek pengamatan. Dalam penelitian yang dilakukan, aktivitas yang menjadi fokus antara lain: kehadiran dosen dan mahasiswa, kemampuan dosen memotivasi mahasiswa, kemampuan menyampaikan materi perkuliahan, kemampuan menerapkan metode pembelajaran, ketersediaan media pembelajaran, alokasi waktu hingga partisipasi dan perhatian mahasiswa dalam kelas.

Meskipun demikian, tidak semua aktivitas kegiatan perkuliahan berjalan dengan lancar. Ada beberapa kendala yang dihadapi oleh tenaga pengajar maupun mahasiswa. Hal tersebut tentu menggangu jalannya perkuliahan sehingga diperlukan adanya pemetaan kendala-kendala apa saja yang mengganggu jalannya perkuliahan.

Dari hasil penelitian yang telah dilakukan dapat disimpulkan bahwa selama proses interaksi dosen dan mahasiswa pada tingkat kehadiran mahasiswa telah berjalan dengan baik. Hal itu dibuktikan dari hasil observasi bahwa rata-rata kehadiran mahasiswa dalam kelas adalah lebih dari $80 \%$ atau berada pada kategori baik. Selanjutnya adalah kemampuan dosen dalam memotivasi mahasiswa. Dari hasil observasi serta penilaian dari mahasiswa, menunjukkan hasil yang sama bahwa dosen-dosen MSD telah mampu memotivasi mahasiswa dengan baik. Pada aspek perhatian mahasiswa, dari hasil penelitian diperoleh bahwa perhatian mahasiswa akan lebih meningkat apabila pemberian pengantar ataupun materi perkuliahan hanya sebentar selanjutnya adalah memfokuskan mahasiswa pada tugas berupa praktik langsung. Selain itu, interaksi antara peserta didik juga berjalan dengan baik dan terjadi dengan menggunakan pendekatan personal sehingga dosen mampu memahami mahasiswanya dengan baik dan proses pembelajaran berjalan dengan menyenangka.
Pelaksanaan pembelajaran merupakan proses dari adanya interaksi antara dosen dan mahasiswa. Dari hasil penelitian menunjukkan bahwa proses interaksi antara mahasiswa dan dosen terjadi secara personal. Hal tersebut sesuai dengan kesimpulan yang diperoleh dari hasil wawancara dengan dosen-dosen MSD bahwa ada banyak kendala yang dihadapi yang berkaitan dengan mahasiswa. Solusi yang digunakan oleh dosen adalah lebih banyak menggunakan pendekatan personal.

\section{Penilaian Hasil Belajar}

Pada aspek pembelajaran, selain perencanaan dan pelaksanaan pembelajaran aspek yang perlu diperhatikan adalah penilaian hasil belajar. penilaian hasil belajar baik yang dilakukan pada setiap pertemuan maupun di tengah dan akhir semester. Penilaian hasil belajar pada Program Studi DKV MSD Yogyakarta dilakukan dengan penilaian berkala yaitu ujian tengah semester, ujian akhir semester dan penilaian terhadap tugas-tugas harian yang dikerjakan oleh mahasiswa. Selain itu, pada saat perkuliahan dosen juga melakukan penilaian langsung terhadap proses belajar mahasiswa selama dikelas.

Penilaian hasil belajar merupakan hal yang wajib dilakukan dalam proses pelaksanaan pembelajaran. Penilaian hasil belajar dilakukan untuk mengukur seberapa besar kemampuan yang telah dikuasai oleh peserta didik. penilaian hasil belajar juga mengukur sejauh mana ketercapaian tujuan yang diharapkan dengan hasil yang diperoleh oleh mahasiswa.

Dari hasil penelitian yang telah dilakukan dapat disimpulkan bahwa penilaian hasil belajar yang dilakukan oleh dosen-dosen MSD telah sesuai dengan Peraturan Menteri Pendidikan dan Kebudayaan Nomor 49 Tahun 2014 tentang penilaian pembelajaran. Dalam keputusan tersebut penilaian hasil belajar dilakukan secara berkala yang dapat berbentuk ujian, pelaksanaan tugas, dan pengamatan oleh dosen. Selain itu, ujian dapat diselenggarakan 
melalui ujian tengah semester, ujian akhir semester, ujian akhir program studi dengan penilaian hasil belajar dinyatakan dengan huruf $A, B, C, D$, dan $E$.

\section{Sarana dan Prasana}

Dalam pelaksanaan pembelajaran, ada banyak komponen yang mendukung dalam kesuksesannya. Komponen lain yang mendukung terlaksananya pembelajaran adalah sarana dan prasarana yang tersedia. Dari hasil penelitian yang diperoleh menunjukkan bahwa ketersediaan sarana dan prasarana sebagai pendukung perkuliahan dianggap telah cukup untuk memenuhi kebutuhan perkuliahan.

Ketersediaan sarana prasarana pada suatu lembaga pendidikan akan sangat menunjang pelaksanaan pembelajaran. Dengan ketersediaan jumlah sarana dan prasarana yang memenuhi kebutuhan perkuliahan, pembelajaran akan berjalan dengan lancar. Sarana diartikan sebagai semua perangkat peralatan, bahan dan perabot yang secara langsung digunakan dalam proses pendidikan. Sementara pra-sarana diartikan sebagai perangkat perlengkapan dasar yang secara tidak langsung menunjang proses pendidikan.

Berdasarkan hasil observasi yang diperoleh terungkap bahwa pada ruangan kelas untuk mata kuliah-mata kuliah praktik jumlahnya lebih banyak jika dibandingkan dengan mata kuliah teori. Walaupun demikian, pada pelaksanaan mata kuliahmata kuliah praktik, mahasiswa tidak langsung langsung diterjunkan untuk praktik melainkan ada pembekalan teori terlebih dahulu.

Dari hasil penelitian yang telah dilakukan di MSD Yogyakarta dapat disimpulkan bahwa sarana prasarana yang tersedia sebagai pendukung perkuliahan sebagian besar telah memenuhi kebutuhan perkuliahan walaupun ada beberapa kendala, namun tidak menjadi hambatan bagi dosen dalam menjalankan proses perkuliahan. Meskipun telah memenuhi kebutuhan perkuliahan, namun belum sepenuhnya memenuhi standar minimal yang tercantum dalam Permendikbud nomor. 49 tahun 2014. Seperti belum tersedianya sarana prasarana penunjang untuk berolahraga dan berkesenian.

Dalam setiap pelaksanaan pembelajaran di lembaga pendidikan manapun, tentunya tidak akan terlepas dari segala hambatan maupun kendala. Namun, tidak hanya kendala dan hambatan saja, faktorfaktor pendukung sebuah keberhasilan dari pelaksanaan pembelajaran juga selalu ada demi kelangsungannya. Dalam pelaksanaan pembelajaran di Program studi Desain Komunikasi Visual MSD Yogyakarta juga tidak lepas dari adanya hambatan-hambatan, namun selain adanya hambatan-hambatan, MSD juga memiliki faktor pendukung kuat yang selalu menyokong keberhasilan pelaksanaan pembelajaran. Berikut adalah beberapa faktor pendukung keberhasilan pelaksanaan pembelajaran di Program studi Desain Komunikasi Visual ASRD MSD Yogyakarta yaitu: (1) Faktor kedekatan dan komunikasi personal antara dosen dan mahasiswa yang terjalin dengan baik membuat pelaksanaan pembelajaran menjadi menyenangkan. (2) Pemanfaatan media-media pembelajaran dan alat bantu belajar lainnya yang selalu up to date dalam pembelajaran membuat suasana belajar menjadi menyenangkan dan sesuai dengan perkembangan teknologi. (3) Kebebasan yang diberikan kepada mahasiswa dalam menentukan minat bakat yang akan ditekuninya membuat mahasiswa betah belajar dan mudah untuk mempelajari tentang desain komunikasi visual serta ketrampilan mahasiswa yang selalu terasah.

Selanjutnya setelah dipaparkan tentang faktor pendukung keberhasilan pelaksanaan pembelajaran pada Program studi Desain Komunikasi Visual MSD Yogyakarta, akan dijelaskan pula beberapa hambatan yang dialami dalam pelaksanaan pembelajaran, yaitu: (1) belum sesuainya silabus yang ada di MSD Yogkarta dengan Permendikbud no. 49 tahun 2014 serta tidak adanya koordinasi antara tiap-tiap dosen dalam penyusunan silabus. (2) Do- 
sen-dosen belum sepenuhnya memahami tentang pentingnya melakukan apersepsi diawal perkuliahan maupun refleksi pembelajaran di akhir pertemuan. (3) Kurang tertibnya dosen dalam mengikuti jadwal perkuliahan yang telah dibuat dengan bukti banyaknya dosen yang datang terlambat 15 hingga 30 menit dari jadwal yang telah ditentukan yang kadang tanpa pemberitahuan alasan yang jelas. (4) Kurang tertibnya mahasiswa dalam mengikuti perkuliahan membuat suasana perkuliahan menjadi tidak kondusif. (5) Masih adanya dosen yang belum membuat kontrak atau kesepakatan belajar dengan mahasiswa baik meliputi alokasi waktu, tugas, kehadiran mahasiswa maupun proporsi besarnya nilai-nilai tugas, UTS maupun UAS.

\section{Simpulan dan Saran}

\section{Simpulan}

Berdasarkan hasil analisis data dan pembahasan, dapat ditarik kesimpulan bahwa pelaksanaan pembelajaran di Program Studi DKV MSD Yogyakarta belum sesuai dengan dengan standar atau kriteria yang telah dirumuskan yaitu Permendikbud nomor. 49 tahun 2104 dan beberapa teori yang digunakan. Pada aspek perencanaan pembelajaran, silabus belum sesuai dengan Standar Proses Pembelajaran Peraturan tersebut. Pada aspek pelaksanaan pembelajaran, terdapat ketidaksesuaian dengan Gagne's nine events of instruction yaitu pada tahap menyimpulkan atau refleksi pembelajaran. Interaksi antara dosen dan mahasiswa berjalan dengan baik karena dosen dan mahasiswa menggunakan komunikasi personal. Penilaian hasil belajar telah sesuai dengan Standar Penilaian Pembelajaran Permendikbud Nomor 49 Tahun 2014. Hasil penilaian mahasiswa menunjukkan bahwa pelaksanaan pembelajaran di DKV MSD berada pada kategori baik dengan nilai 3,20. Sehingga, pelaksanaan pembelajaran pada Program Studi DKV MSD Yogyakarta masih perlu disesuaikan dengan Standar Nasional Pendidikan Tinggi Permendikbud No. 49 Ta- hun 2014 agar pelaksanaan pembelajaran dapat terselenggara dengan baik.

Saran

Dari hasil penelitian mengenai evaluasi pelaksanaan pembelajaran, dapat disarankan beberapa hal yaitu bagi Program Studi DKV MSD dan tenaga pengajar. Bagi Prodi, Perlunya pemberian pembekalan kepada dosen-dosen tentang perencanaan pembelajaran yang matang dan koordinasi tentang penyususnan silabus sehingga adanya keseragamaan yang sesuai dengan Peraturan yang berlaku. Selain itu, perlunya acuan format yang jelas terkait isi silabus sehingga terjadi pelaksanaan pembelajaran yang sesuai dengan teori-teori pembelajaran. Bagi tenaga pengajar, Perlu adanya membuat kesepakatan belajar yang jelas dengan mahasiswa terkait alokasi waktu, kehadiran mahasiswa, proporsi penilaian maupun punishment yang diterima apabila terjadi pelanggaran. Hal tersebut perlu jelas dibuat dan dipahami oleh mahasiswa maupun dosen sendiri. Sehingga, bukan sekedar komitmen dan konsekuensi.

\section{Daftar Pustaka}

Arikunto, S. \& Jabar, C. S. A. (2004). Evaluasi program pendidikan. Jakarta: Bumi Aksara.

Depdiknas. (2010). Buku pedoman kerangka kualifikasi nasional indonesia edisi 1. Jakarta: Departemen Pendidikan Nasional.

Gafur, A. (2012). Desain pembelajaran: konsep, model dan aplikasinya dalam perencanaan pelaksanaan pembelajaran. Yogyakarta: Penerbit Ombak.

Gagne, R. M., et. al, (2004). Principles of instructional design $5^{\text {the }}$. California: Thomson Learning.

Gunadha, R. (2013). Muhaimin Iskandar: 600 ribu sarjana jadi pengangguran. Diakses tanggal 10 November 2013 dari 
http:/ /www.tribunnews.com/nasi onal/2013/11/03/muhaiminiskandar-600-ribu-sarjana-diindonesia-jadi-pengangguran.

Menteri Pendidikan dan Kebuadayaan. (2014). Peraturan menteri pendidikan dan kebudayaan RI Nomor 49, Tahun 2014, tentang Standar Nasional Pendidikan Tinggi.

Prasetyahadi, J. FX., et al. (2012). Buku panduan akademi seni rupa dan disain MSD Yogyakarta. Tidak diterbitkan, ASRD MSD Yogyakarta, Yogyakarta.
Sugiyono. (2013). Memahami penelitian kualitatif. Bandung: CV. Alfabeta.

Suryowati, E. (2013). BPS: Pengangguran di Indonesia Mencapai 7, 24 Juta Jiwa. Diakses tanggal 10 November 2013 dari

http:/ / bisniskeuangan.kompas.co $\mathrm{m} / \mathrm{read} / 2014 / 11 / 05 / 145400626 / \mathrm{ar}$ tikel-detail-komentar-mobile.html.

Widoyoko, E. P. (2013). Teknik Penyusunan Instrumen Penelitian. Yogyakarta: Pustaka Pelajar. 